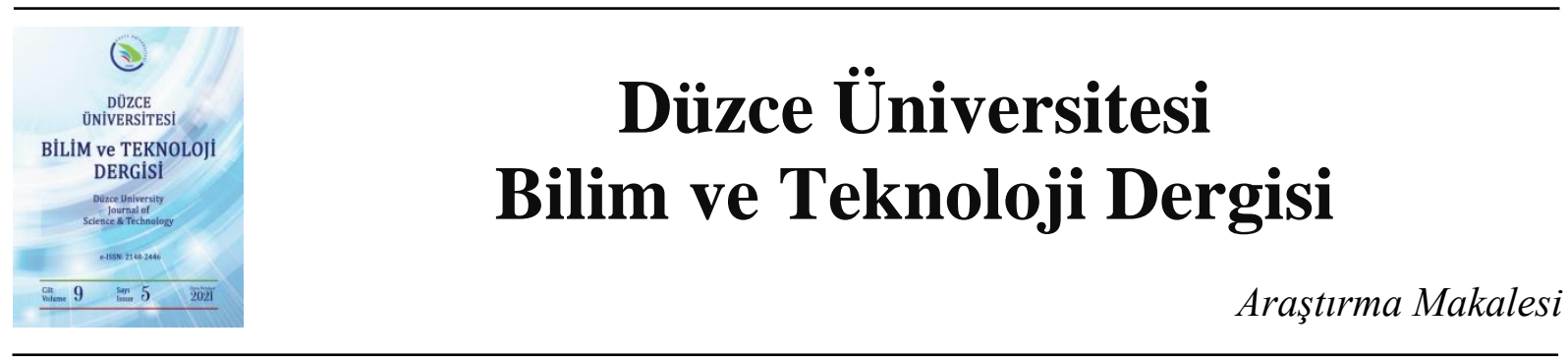

\section{Uçucu Külün Yapı Malzemelerinin Mukavemeti ve Bağlayıcılığına Etkisinin Araştırılması}

\author{
Deltem ÇUBUK ${ }^{\mathrm{a}, *}$, (D) Metin GÜRÜ ${ }^{\mathrm{b}}$, DDeniz ARSLANc, (iDOnur ÖZDEMİ ${ }^{\mathrm{d}}$ \\ ${ }^{a}$ Ulaştırma ve Altyapı Bakanlı̆̆l, Ankara, TÜRKIYYE \\ ${ }^{b}$ Kimya Mühendisliği Bölümü, Mühendislik Fakültesi, Gazi Üniversitesi, Ankara, TÜRKİYE \\ 'İnşaat Mühendisliği Bölümü, Mühendislik ve Doğa Bilimleri Fakültesi, Konya Teknik Üniversitesi, Konya, \\ TÜRKIYE \\ ${ }^{d}$ Yatırım ve İnşaat Müdürlüğü, Kastamonu İl Özel İdaresi, Kastamonu, TÜRKIYYE \\ *Sorumlu yazarın e-posta adresi: melcubuk@yahoo.com \\ DOI:10.29130/dubited.886150
}

\begin{abstract}
ÖZ
Dünyada yaşanılan iklim değişikliği nedeniyle enerji temini gibi hafif yapı malzemelerinin kullanımına yönelik araştırmalar son yıllarda hız kazanmıştır. Tasarım uygulamalarının birçoğu iklimi de dolaylı olarak etkileyecek nitelikte olduğundan yapılan araştırmalar, fosil yakıtlara bağlı olmaksızın, düşük karbonlu bir geleceği teşvik etmeye yardımcı olacaktır. Yapı malzemelerinde aranan özellikler; ekonomiklik, dayanım, insan sağlığına ve çevreye olumsuz etkisinin bulunmamasıdır. Türkiye'de kömür yakıtlı termik santrallerde 2017 yılında 63 milyon ton linyit elektrik üretimi amacıyla tüketilmiştir. Yakılan kömürlerden elde edilen uçucu küller, depolama alanlarında depolanmakta rüzgar, yer altı ve yer üstü suyu ile taşınarak çevre ve insan sağlığını olumsuz yönde etkilemektedir. Bu çalışmada, puzolan özellik gösteren, kireç oranı yüksek ve atık malzeme nitelendiğinde Yatağan Termik Santrali uçucu külü kullanılmıştır. Standart bağlayıcı malzemeler olarak bilinen çimento, kireç ve alçı yerine kullanılabileceği düşünülen uçucu külün bağlayıcı özelliği ve malzemenin mukavemeti üzerine araştırma yapılmıştır. Deneysel çalışmalarda üretilen 4x4x16 cm ebatlarındaki numunelere basınç ve eğilme deneyleri uygulanarak mekanik dayanımları belirlenmiştir. Deneyler sonucunda 4.4 nolu numunede en yüksek eğilme dayanımı 2,39 MPa, 3.1 nolu numunede en yüksek basınç dayanımı 10,03 MPa olarak bulunmuştur. Yapılan çalışmalar sonucunda puzolan özelliğe sahip uçucu küllerin bağlayıcı etkisi görülmüş ve dolgu malzemesi olarak mekanik dayanımda artış sağladığı tespit edilmiştir.
\end{abstract}

Anahtar Kelimeler:Băglayıcı malzemeler, Kil, Kireç,Uçucu kül

\section{Investigation of the Effect of Fly Ash on the Strength and Binding of Building Materials}

\begin{abstract}
Due to the climate change experienced in the world, researches on the use of light building materials such as energy supply have gained speed in recent years. Since many of the design applications will also indirectly affect the climate, researches will help promote a low carbon future, regardless of fosil fuels. Properties required in building materials; economy, strength, human health and environment has no negative impact. Coal-fired thermal power plants in 2017 was 63 million tons of lignite consumed for the purpose of electricity generation in Turkey. The fly ashes obtained from the burned coals are stored in storage areas, and they are carried by wind, underground and groundwater, adversely affecting the environment and human health. In this study, Yatağan Thermal Power Plant waste fly ash, which has puzolan feature, high lime ratio, is used. Research was conducted
\end{abstract}


on strength of material and the binding properties of fly ash, which is thought to can be used instead of cement, lime and plaster, known as Standard binding materials. Mechanical strengths were determined by applying pressure and bending tests to samples of certain sizes produced in experimental studies. As a result of the experiments, the highest bending strength was determinated $2.39 \mathrm{MPa}$ in sample 4.4, the highest compressive strength was determinated $10.03 \mathrm{MPa}$ in sample 3.1. As a result of the studies, the binding effect of the pozzolan fly ashes was observed and it was determined that the mechanical strength was increased by as filling material.

Keywords:Binder materials, Clay, Lime, Fly ash

\section{GIRIS}

Giderek büyüyen inşaat sektörü, teknolojik gelişmeler ile birlikte daha emniyetli, ekonomik ve çevreye duyarlı mühendislik malzemelerinin hayat bulduğu bir sektör olarak karşımıza çıkmaktadır. Dünyada bir sorun halinde bulunan katı atık problemi ve bu atıkların değerlendirilmesi konusunda inşaat sektöründe de çalışmalar hız kazanmıştır. Yapılan geniş çaplı bir araştırma ile uçucu küllerin inşaat sektöründe çok büyük kullanım potansiyelinin bulunduğu, özellikle çimento, beton ve yap1 malzemelerinin üretiminde daha yaygın olduğu, Türkiye'de ve dünyada bu atı̆̆ın değerlendirilmesi ile ülke ekonomisine katkı sağlanabileceğinin yanı sıra hem doğal hammadde ile ekolojik dengenin korunması hem de çevre kirliliğinin önlenmesinin mümkün göründüğü belirlenmiştir [1].

Çiçek ve Çinçin [2] tarafından yapılan çalışmada, termik santral bacalarında tutulan uçucu küllerin, çimento ve hidrolik bağlayıcılarla birlikte performans artırıcı olarak uygulanabileceği, uçucu kül ve kireç karışımlarının buharla sertleştirilmesiyle hazırlanan silindirik tuğla numunelerine yapılan testler sonucu uçucu kül/kireç tuğlalarının betona alternatif bir ürün olabileceği düşünülmüştür. Puzolonik özellik taşıyan maddelerin yapı sektöründe kullanılmasına ve geçirimsizlik özelliklerine etkisini araştıran Şadoğlu ve Çalık [3], zengin silis ve alümin içeriğine sahip olan kilin amorf yapıda değil de kristalli yapıda olmasından ötürü puzolanik aktiviteye sahip olmadığı, perlit gibi doğal puzolanların ise silikat $\left(\mathrm{SiO}_{2}\right)$ ve alüminat $\left(\mathrm{Al}_{2} \mathrm{O}_{3}\right)$ esaslı olmalarına rağmen yetersiz $\mathrm{CaO}$ içeriği nedeniyle büyük çoğunluğunun kendi başlarına bağlayıcılık özelliğine sahip olmadığı, bu nedenle uygun su içeriğinde ve normal ortam sıcaklığında kireç ve çimento gibi yüksek $\mathrm{CaO}$ içeren materyallerle bu eksikliğin giderilebileceğini belirtmiş, kireç ve perlit ilavesiyle yüksek plastisiteli kil zeminin geçirimlilik katsayısının artan perlit oranıyla orantılı şekilde azaltmışlardır. Uçucu küllerin bağlayıcılık özelliğinin iyi olmasından ötürü deniz dibi tarama malzemesi-uçucu kül- atık döküm kumu ile yapay hafif agrega üretimi çalışan Erdoğan ve Başar [4], bu maddelerin hammadde olarak kullanımı/geri kazanımı ile tüm agrega serilerinde, sinterleme sıcaklığı artışı ile yapay hafif agregaların mekanik, mikroyapısal ve mineralojik özelliklerinde iyileşme olduğunu belirlemişlerdir.

Uçucu kül, düşük kalorili kömürlerin toz haline getirilerek yakılması sonucu bacadan çıkan gazla birlikte yukarıya sürüklenen çok ince kül parçacıklarıdır. Çok hafif olan bu uçucu küller, bacanın üst kısmında elektrofiltre veya siklon adı verilen toz tutucuların alt kısmında bunkerlerde biriktirilir ve periyodik olarak santral dışına alınırlar. Baca gazları ile sürüklenen ve hava ile temas ederek ani soğuma ile puzolan özellik kazanan uçucu kül tanecikleri genellikle küresel yapıda olup büyüklükleri 1-200 $\mu \mathrm{m}$ arasında değişmekte olup aglomere şeklinde yapıya sahiptir [5]. Nordin vd. [6] uçucu külün puzolonik özellikleri nedeniyle portland çimento betonu üretiminde ek malzeme olarak kullanılabileceğini ve uçucu külün fiziksel, mineralojik ve kimyasal özelliklerinin uçucu külün performansını büyük ölçüde etkilediğini, yüksek incelik ile düşük karbon içeriğinin bir portland çimento betonuna kıyasla daha düşük su ihtiyacını gerektirdiğini belirlemiştir. Kerpiç malzemesi yapım tekniği ve özelliklerinin iyileştirilebilmesi için yapılan araştırmaların incelendiği çalışmada uçucu küllü kerpiçlerin basınç dayanımlarının çimentolu ve samanlı kerpiçlere göre daha iyi olduğu belirtilmiştir [7]. Atık malzemelerin tuğlalarda kullanılarak kil malzemesi tüketimini ve karbon ayak izini azaltılabilmek için yapılan çalışmada uçucu kül ve toprak malzeme kullanılarak üretilen kil tuğla numunelerinin basınç dayanımının, uçucu kül içermeyen kil tuğlalara kıyasla daha düşük olduğu ve \%20'ye kadar uçucu kül içeren tuğlaların basınç dayanımının, mevzuat gereklerini karşıladığı, uçucu 
kül içeren kil tuğlaların ekonomik çözüme götüren daha sürdürülebilir tuğlaların üretilmesinde yardımcı olabileceği sonucuna varılmıştır [8].

Bu çalışmada, atık statüsünde bulunan puzolan özellikte uçucu külün mukavemete ve bağlayıcılığa etkisinin araştırılması, standart bağlayıcı malzeme olarak bilinen ve Türkiye inşaat sektöründe en büyük üretim ve kullanım alanına sahip çimentonun ve hammaddelerinin su ile girdikleri reaksiyonlar sonucu çıkardıkları $\mathrm{CO}_{2}$ gazı ve buna bağlı sera gazı emisyonlarını azaltmaya yönelik ülkemizin de imzaladığı Kyoto Protokolü’ne istinaden yeni malzemelerin bulunması üzerine çalışılmıştır.

\section{MALZEME VE YÖNTEM}

\section{A. KULLANILAN MALZEMELER}

Deneysel çalışmalarda, doğada bulunuşu ve temini kolay malzemeler olarak bilinen kireç, kil ve atık materyal olarak uçucu kül kullanılmıştır. Bu malzemelerden oluşturulan belirli oranlarda ki karışımlar standart $4 \times 4 \times 16 \mathrm{~cm}$ ebatlarındaki kalıplara dökülerek numuneler elde edilmiş, otoklav ortamındaki buhar kürlerinin ardından mekanik deneylere tabi tutularak dayanımları test edilmiştir. Bir malzemenin dayanımı (strength), çok büyük şekil değiştirmeden taşıyabileceği kuvveti ifade etmektedir. Üretilen numunelere, mekanik deneyler olarak basınç dayanımı (compressive strength) ve eğilme dayanımı (bending strength) deneyleri yapılmış ve üretilen malzemelerin mukavemeti belirlenmiştir. Uçucu külün bağlayıcılığının tespiti ve bağlayıcılığa etkisi ile geri dönüşümü sağlanarak kullanılabilirliği ve çevreye verdiği zararın en aza indirgenmesi amaçlanmıştır.

$\mathrm{Bu}$ çalışmada kullanılan uçucu kül Yatağan Termik Santrali'nden temin edilmiştir. Bu külün çalışmalarımızda kullanılmak üzere seçilmesinin nedeni; TS EN 197-1 [9], ASTM C 618 [10] ve TS EN 450-1 [11] standartlarında istenilen kimyasal bileşen sınırlarına uygunluğudur. Yatağan uçucu külü reaktif kireç miktarının \%10'a yakın olması TS EN 197-1'e göre W (kalkersi) sınıfında, ASTM C 618 standardına göre $\mathrm{SiO}_{2}+\mathrm{AI}_{2} \mathrm{O}_{3}+\mathrm{Fe}_{2} \mathrm{O}_{3}$ değerinin \%70'in üzerinde olması $\mathrm{F}$ sinıfı (silissi) ve $\mathrm{CaO}$ miktarının \%10’u geçmesi kireçsi kül sınıfında olduğunu göstermektedir. Buna göre, Yatağan Uçucu Külü ASTM C 618 [10] ve TS 450-1 [11]'deki $\mathrm{SiO}_{2}+\mathrm{AI}_{2} \mathrm{O}_{3}+\mathrm{Fe}_{2} \mathrm{O}_{3}>70$ koşulunu sağlamaktadır. Yatağan Termik Santrali uçucu külünün mineralojik bileşimi camsı faz karışımından oluşmaktadır. Başlıca kristal fazlar; kuvars, anortit, sanidin, albit olmak üzere diğer fazlar anhidrit, serbest kireç, dolomit ve hematitdir. Yatağan uçucu külünde camsı fazın, $27^{\circ} 2 \theta^{\prime}$ da en çok duruma gelmesi ve içine $31-32^{\circ} 2 \theta$ değerini de alacak şekilde yayılması, camsı fazın hem kireçsi hem silissi yapıda olmasından kaynaklanmaktadır. Dolayısıyla, bu küldeki camsı faz kalsiyum alüminosilikat bileşimli yapıya sahiptir. Yatağan uçucu külü, homojen olmayan tane büyüklük dağılımına sahiptir. Büyüklükleri 0,5$30 \mu \mathrm{m}$ arasında değişen ve çoğunluğu düzensiz şekilli, köşeli olan taneciklerden oluşmaktadır. $3 \mu \mathrm{m}$ ve altındaki büyüklüklerde tam küresel tanecikler de bulunmaktadır. Yapı içinde masif kütle halinde anortit, sanidin (K-feldspat), albit olduğu, anortit mineralinin kütle halinde olması, kömürün yanmas1 sırasında bozunmadan uçucu küle katılmasından ileri geldiği bilinmektedir [12].

Kullanılan kireç, Afyon Kireç Fabrikası'nda temin edilmiş olup beyaz renkli, sönmüş kireç olup yoğunluğu $1,2 \pm 0,01 \mathrm{~kg} / \mathrm{dm}^{3}$ 'dir. Deneylerde kullanılan kil, Afyonkarahisar Şuhut ilçesi Ağzıkara Göleti inşaatından temin edilmiş olup yoğunluğu $2,58 \pm 0,1 \mathrm{~kg} / \mathrm{dm}^{3}$,Yatağan Termik Santralinden temin edilen uçucu külün yoğunluğu $2.12 \mathrm{~g} / \mathrm{cm}^{3}$ 'dür. Çalışmada kullanılan malzemelerin kimyasal analiz sonuçları Tablo 1'de verilmiştir.

Tablo 1. Kullanılan malzemelerin kimyasal analiz sonuçları

\begin{tabular}{cccccccccccc}
\hline $\begin{array}{c}\text { Oksit } \\
(\%)\end{array}$ & $\mathbf{S i O}_{2}$ & $\begin{array}{c}\mathbf{A l}_{2} \mathbf{O} \\
\mathbf{3}\end{array}$ & $\begin{array}{c}\mathbf{F e}_{2} \mathbf{O} \\
\mathbf{3}\end{array}$ & $\mathbf{S + A + F}$ & $\mathbf{C a O}$ & $\mathbf{M g O}$ & $\mathbf{S O}_{3}$ & $\mathbf{K}_{2} \mathbf{O}$ & $\mathbf{N a}_{2} \mathbf{O}$ & $\mathbf{K K}$ & $\mathbf{C l}^{-}$ \\
\hline UK & 51,50 & 23,08 & 6,07 & 80,65 & 10,53 & 2,42 & 1,32 & 2,54 & 0,77 & 1,06 & 0,0028 \\
Kil & $40-45$ & $35-45$ & $1-5$ & - & $1-5$ & $1-5$ & - & - & - & - & - \\
Kirec & 1,03 & - & - & - & 68,92 & 3,29 & 1,37 & 0,05 & 0,09 & 25,25 & - \\
\hline
\end{tabular}




\section{B. YÖNTEM}

\section{B. 1. Karışım Hesaplarının Yapılması}

Karışım hesapları, çalışmanın başlangıcında deneme yanılma metodu kullanılarak tespit edilmeye çalışılmıştır. Değişkenler olarak uçucu kül ve kil alınarak değişik oranlarda seriler elde edilmiştir. Bunun için öncelikli denenecek karışım hesapları ve seriler Tablo 2'de gösterilmiştir.

Tablo 2. Kullanılan malzemelerin karışım oranları

\begin{tabular}{|c|c|c|c|c|c|}
\hline Seri No & $\begin{array}{c}\text { Uçucu Kül } \\
(\%)\end{array}$ & $\begin{array}{l}\text { Kil } \\
(\%)\end{array}$ & $\begin{array}{c}\text { Kireç } \\
(\%)\end{array}$ & $\begin{array}{c}\text { Numune } \\
\text { Adeti } \\
(4 \times 4 \times 16 \mathrm{~cm}) \\
\end{array}$ & $\begin{array}{l}\text { Su } \\
(g r)\end{array}$ \\
\hline 1.1 & 50 & 50 & 0 & 3 & 170 \\
\hline 1.2 & 47,5 & 47,5 & 5 & 3 & 157 \\
\hline 1.3 & 45 & 45 & 10 & 3 & 151 \\
\hline 1.4 & 42,5 & 42,5 & 15 & 3 & 145 \\
\hline 1.5 & 40 & 40 & 20 & 3 & 135 \\
\hline 1.6 & 37,5 & 37,5 & 25 & 3 & 121 \\
\hline 1.7 & 35 & 35 & 30 & 3 & 146 \\
\hline 2.1 & 60 & 40 & 0 & 3 & 161 \\
\hline 2.2 & 57 & 38 & 5 & 3 & 166 \\
\hline 2.3 & 54 & 36 & 10 & 3 & 162 \\
\hline 2.4 & 51 & 34 & 15 & 3 & 151 \\
\hline 2.5 & 48 & 32 & 20 & 3 & 137 \\
\hline 2.6 & 45 & 30 & 25 & 3 & 89 \\
\hline 2.7 & 42 & 28 & 30 & 3 & 75 \\
\hline 3.1 & 70 & 30 & 0 & 3 & 156 \\
\hline 3.2 & 66,5 & 28,5 & 5 & 3 & 148 \\
\hline 3.3 & 63 & 27 & 10 & 3 & 141 \\
\hline 3.4 & 59,5 & 25,5 & 15 & 3 & 127 \\
\hline 3.5 & 56 & 24 & 20 & 3 & 112 \\
\hline 3.6 & 52,5 & 22,5 & 25 & 3 & 78 \\
\hline 3.7 & 49 & 21 & 30 & 3 & 81 \\
\hline 4.1 & 80 & 20 & 0 & 3 & 155 \\
\hline 4.2 & 76 & 19 & 5 & 3 & 145 \\
\hline 4.3 & 72 & 18 & 10 & 3 & 154 \\
\hline 4.4 & 68 & 17 & 15 & 3 & 120 \\
\hline 4.5 & 64 & 16 & 20 & 3 & 114 \\
\hline 4.6 & 60 & 15 & 25 & 3 & 102 \\
\hline 4.7 & 56 & 14 & 30 & 3 & 154 \\
\hline
\end{tabular}

$\mathrm{Bu}$ oranlar denenerek hazırlanan numunelerin bir kısmında doğal kurutma (laboratuvar ortam şartları, sıcaklık: $21 \pm 2^{\circ} \mathrm{C}$, bağ $\left.11 \mathrm{nem}: \% 44 \pm 10\right)$ esnasinda $4-5$ gün sonunda ve kür ortamları esnasında (1 saatlik buhar kürü sonrası 24 saat beklemede) çatlamalar, kırılmalar ve dağılma gibi şekil değişiklikleri gözlenmiştir. Oluşan bu olumsuzlukların kil oranı yüksek veya genellikle uçucu kül oran1 \%50'den düşük olan numunelerde meydana geldiği görülmüştür. Buna bağlı olarak çalışmaların 
devamı \%50'den büyük uçucu kül ilaveleri içeren numunelerde yapılmıştır. \%50 uçucu kül-\%50 kil oranından başlamak üzere, ön çalışmalardan elde edilen başlıca oranlar \%60 uçucu kül-\%40 kil, \%70 uçucu kül-\%30 kil, \%80 uçucu kül-\%20 kil üzerinde seri başları elde edilmiş olup bu ana seriler dahilinde uçucu kül ve kil oranları sabit tutularak kireç oranlarında ki \%0 ila \%30 arasındaki değişikliklerle oluşturulan yeni serilerle çalışmanın devamı sağlanmıştır. Deneysel testlere tabi tutulacak karışımlar Tablo 3'de verilmiştir.

Tablo 3. Deneysel testlere tabi tutulan seriler.

\begin{tabular}{|c|c|c|c|c|}
\hline \multirow[b]{2}{*}{ Seri No } & \multicolumn{4}{|c|}{$\begin{array}{c}\text { Ăğırlıklar } \\
(g r)\end{array}$} \\
\hline & Uçucu Kül & Kil & Kireç & Su \\
\hline 1.1 & 262,27 & 307,71 & 0,00 & 170 \\
\hline 1.2 & 249,16 & 292,33 & 17,59 & 157 \\
\hline 1.3 & 236,04 & 276,94 & 35,17 & 151 \\
\hline 1.4 & 222,93 & 261,56 & 52,76 & 145 \\
\hline 1.5 & 209,82 & 246,17 & 70,35 & 135 \\
\hline 1.6 & 196,70 & 230,78 & 87,94 & 121 \\
\hline 1.7 & 183,59 & 215,40 & 105,52 & 146 \\
\hline 2.1 & 314,73 & 246,17 & 0,00 & 161 \\
\hline 2.2 & 298,99 & 233,86 & 17,59 & 166 \\
\hline 2.3 & 283,25 & 221,55 & 35,17 & 162 \\
\hline 2.4 & 267,52 & 209,24 & 52,76 & 151 \\
\hline 2.5 & 251,78 & 196,94 & 70,35 & 137 \\
\hline 2.6 & 236,04 & 184,63 & 87,94 & 89 \\
\hline 2.7 & 220,31 & 172,32 & 105,52 & 75 \\
\hline 3.1 & 367,18 & 184,63 & 0,00 & 156 \\
\hline 3.2 & 348,82 & 175,40 & 17,59 & 148 \\
\hline 3.3 & 330,46 & 166,16 & 35,17 & 141 \\
\hline 3.4 & 312,10 & 156,93 & 52,76 & 127 \\
\hline 3.5 & 293,74 & 147,70 & 70,35 & 112 \\
\hline 3.6 & 275,39 & 138,47 & 87,94 & 78 \\
\hline 3.7 & 257,03 & 129,24 & 105,52 & 81 \\
\hline 4.1 & 419,64 & 123,08 & 0,00 & 155 \\
\hline 4.2 & 398,65 & 116,93 & 17,59 & 145 \\
\hline 4.3 & 377,67 & 110,78 & 35,17 & 154 \\
\hline 4.4 & 356,69 & 104,62 & 52,76 & 120 \\
\hline 4.5 & 335,71 & 98,47 & 70,35 & 114 \\
\hline 4.6 & 314,73 & 92,31 & 87,94 & 102 \\
\hline 4.7 & 293,74 & 86,16 & 105,52 & 154 \\
\hline
\end{tabular}

\section{B. 2. Numune Üretimi}

\section{B.2.1. Karışım Hazırlama}

Değişik serilere ait hamurlar oluşturulmadan önce temin edilen kil, öğütme değirmenlerinde 2 saatlik ögütülmeye tabi tutulmuş ve bünyesinde bulunan topaklaşma en az değerlere indirilmiştir. Ögütülme işleminden sonra kilin elek analizi yapılarak gereken tane boyutuna indirilmesi sağlanmış, içerisinde bulunan $1 \mathrm{~mm}$ üstü partiküllerin ayrışması sağlanmıştır. Öğütülen ve elek analizine tabi tutulan kil karışıma girmeden önce de etüvde kurutularak nem içeriğinin uçurulması sağlanmıştır. Uçucu kül ve 
sönmüş kireç hiçbir ön işleme tabi tutulmadan direkt karışıma ilave edilmiş ve tüm bileşenler yoğurma suyu eklenmeden karıştırılmıştır. Karışımın eşit dağılımının ardından TS EN 196-3 [13] dikkate alınarak yoğurma suyu azar azar eklenmiş, plastik kıvama kadar hamurlar tekrar elle yoğrulmuş, şekillendirme için hazır hale getirilmiştir. İnce daneli malzemede istenilen şeklin malzeme numunesinde herhangi bir kırılmaya neden olmadan verilebildiği kıvam plastik kıvam olarak ifade edilmektedir.

\section{B.2.2. Yoğurma Suyu}

Uçucu kül, kil ve sönmüş kireç karışımlarında homojenliğin sağlanması ve sert plastik kıvamda karışım elde edilecek şekilde yoğurma suyu ilavesi yapılmıştır. Yoğurma suyu olarak şebeke suyuTSE 266 [14] kullanılmıştır. Numune bileşenleri homojen şekilde karıştırıldıktan sonra yoğurma suyu azar azar verilmiştir ve buna bağlı olarak 24 saatlik kuruma süresi ile numunenin işlenebilirliği göz önünde tutularak plastiklik kıvamı sağlanmıştır.

\section{B.2.3. Şekillendirme}

Hazırlanan hamurların şekillendirilmesi amacı ile $4 \times 4 \times 16 \mathrm{~cm}$ ebatlarında metal kalıplar yaptırılmış ve şekillendirmede kullanılmıştır. Hazırlanan karışım hamurlarının metal kalıplara dökülmesi el ile yapılmış olup porozitenin en aza indirilmesi için sıkıştırma işlemi şişleme ve plastik çekiç ile kalıp kenarlarına vurulması ile yapılmıştır. Kalıpların zarar görmemesi ve yoğunluğu düşük malzemelerin karışım üzerinde birikmemesi amacıyla titreşim veya vibrasyon işlemine tabi tutulmamıştır.
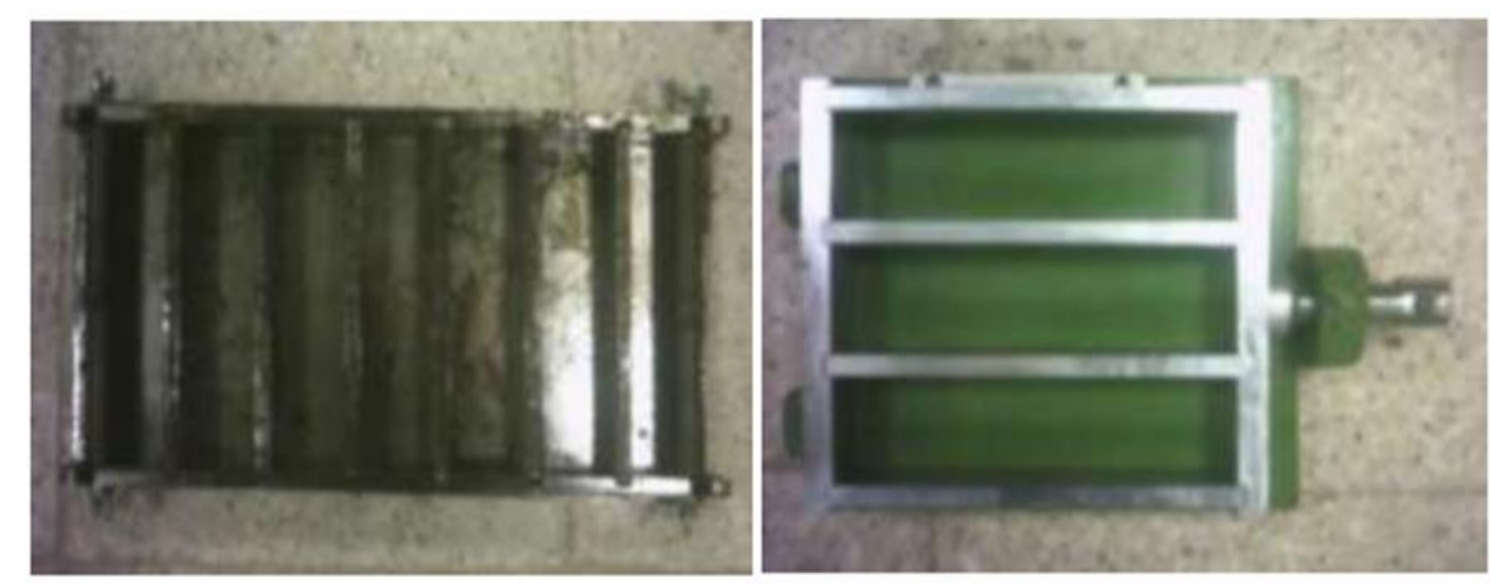

Şekil 1. Metal kaliplar.

\section{B.2.4. Kür İşlemleri}

Hamurlar halinde kalıplara dökülen numuneler, 24 saat sonunda kalıplardan alınarak ve 7 gün boyunca doğal kuruma (laboratuvar şartları ve rötre oluşumu kontrol edilerek) işlemine tabi tutulduktan sonra buhar kürü işlemleri için otoklava konulmuştur. Doygun buhar ortamında $98^{\circ} \mathrm{C}$ sıcaklık, atmosferik basınç, 1 saat süreli kür şartlarında otoklavda tutulan numunelere yaşlandırma yapılmıştır. Kür işlemleri biten numuneler, 1 gün otoklavdan çıkarılmayarak dayanım kazanmaları ve TS EN 12390-2 [15] standardına göre 28 günlük yaş dayanımlarına ulaşmaları sağlanmıştır. Buhar kürü işlemlerinde Hednif marka ve 0,13 MPa basınç üretebilen otoklav kullanılmıştır. 


\section{DENEYSEL ÇALIŞMALAR}

Birim hacim ağırlık tayini; Üretilen malzemenin birim hacim ağırlığının bulunması amacıyla malzemenin yüzeyi parafin ile su geçirimsiz hale getirilmiştir. Arşiment'in suyun kaldırma kuvveti kanunu temel prensibine göre birim hacimdeki kütle miktarı (Dh) Eş. 1'e göre hesaplanmıştır (TS EN 196-3 [13]).

$D h=\frac{M k\left(\mathrm{~g} / \mathrm{cm}^{3}\right)}{V h}$

Eşitlik 1'de belirtilen;

$D h \quad$ : Özgül ağırlık $\left(\mathrm{g} / \mathrm{cm}^{3}\right)$

$M k \quad$ : Kütle (gr)

$V h \quad: \operatorname{Hacim}\left(\mathrm{cm}^{3}\right)$

Numunelerin eğilme dayanımları, TS EN 12390-5 [16] standardına uygun eğilme presi cihazında yapılmış ve Eş. 2 yardımıyla hesaplanmıştır.

$f_{c F}=\frac{(3 x \mathrm{f} \times \ell)}{\left(2 x d_{1} x d_{2}^{2}\right)}$

Eşitlik 2'de belirtilen;

$f_{c f} \quad:$ Eğilmede çekme dayanımı $\left(\mathrm{N} / \mathrm{mm}^{2}\right)$

$f \quad$ : Deney makinesinde kırılma anındaki en büyük yük $(\mathrm{N})$

$\ell \quad$ : Yükleme tablası mesnet arasındaki (serbest) açılık (mm)

$d_{l} \quad:$ Kırılma kesitinin ortalama genişliği (mm)

$d_{2} \quad$ : Kırılma kesitinin ortalama yüksekliği $(\mathrm{mm})$

Basınç dayanım deneyi ise belirli yaştaki numunelerin birim alanının taşıyabileceği yük miktarının belirlenebilmesi ve aynı karışımla üretilen malzemenin gerçek uygulamadaki elemanının taşıyabileceği yük hakkında fikir edinebilmek için birçok yapı malzemeleri üzerinde gerçekleştirilen deneydir [17]. Numunelerin mekanik dayanımlarının tayini bu deney ile gerçekleştirilmiş olup, TS EN 12390-4 [18] standardına uygun basınç deney cihazında yapılmış ve Eş. 3'e göre hesaplanmıştır.

$f c=\frac{F}{A c}$

Eşitlik 3'de belirtilen;

fc $\quad$ : Deney numunesi basınç dayanımı $\left(\mathrm{N} / \mathrm{mm}^{2}\right)$

$F \quad$ : Numunenin kırılma yükü $(\mathrm{N})$

Ac : Uygulama yönüne dik deney numunesi kesit ortalama alanı $\left(\mathrm{mm}^{2}\right)$

\section{SONUCLAR VE TARTIȘMA}

Üretilen 37 adet seriden ilk üretilen 9 numune çıkarılmış ve kalan diğer 28 seri üzerinde testler ve değerlendirmeler yapılmıştır. Üretilen ilk 9 adet serinin kil oranlarının yüksek olması, kolaylıkla kırılmaları ve deforme olmaları nedeniyle $\% 50$ uçucu kül ve üzeri seriler ile testlere devam edilmiştir. 
Sadece 28 adet seriden oluşturulan 84 adet numuneye buhar kürü uygulanmış ve mekanik deneyler yapılmıştır. Yapılan birim hacim ağırlık tayini sonucunda üretilen malzemenin ortalama yoğunluğu $3,167 \mathrm{~g} / \mathrm{cm}^{3}$ bulunmuştur. Üretilen numunelerde kireç miktarının dayanıma etkisi, uçucu kül miktarının dayanıma etkisi, basınç ve eğilme dayanımları arasındaki ilişkinin incelenmesi ve mikroyapı incelemesi yapılmıştır.

\section{A. KİREÇ MIKTARININ YAPI MALZEMESININ DAYANIMINA ETKİSI}

Karışım hesapları, çalışmanın başlangıcında deneme yanılma metodu kullanılarak yapılmaya çalışılmıştır. Deneme sonucu yapılan numunelerin bir kısmında doğal kurutma ve kür ortamları esnasında çatlamalar, kırılmalar ve numunelerin dağılması gibi şekil değişiklikleri gözlenmiştir. Bu oluşan olumsuzlukların kil oranı yüksek (\%30'dan fazla) veya genellikle uçucu kül oranı \%50'den düşük olan numunelerde meydana geldiği görülmüştür. Buna bağlı olarak kirecin yapı malzemelerine etkisini incelemek üzere uçucu kül/kil oranı kütlece 2,33 ve 4 alınarak bu grup deneylerde sabit tutulmuştur. Kür şartları ise doygun buhar ortamında $98^{\circ} \mathrm{C}$ sıcaklık, atmosferik basınç, 1 saat süre ve 28 günlük dayanımları olarak bu grup deneylerin tümünde sabit tutulmuş, kireç miktarı toplam malzemede kütlece yüzde olarak değiştirilmiştir. Değișen kireç miktarına bağlı olarak basınç dayanımının değişimi Şekil 2'de, eğilme deneyi sonuçları Şekil 3'de verilmiştir.

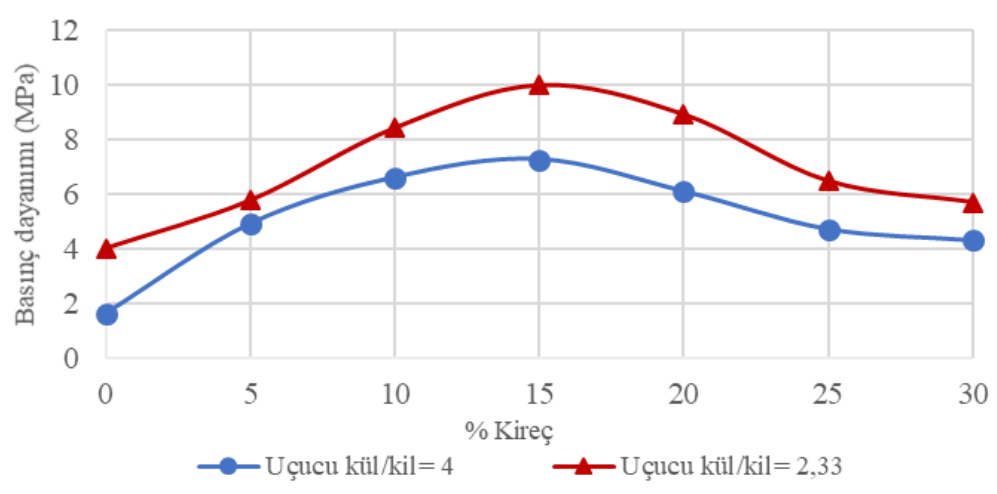

Şekil 2. Basınç dayanımının kireç miktarına bă̆lı olarak değişimi (28 gün yaşta).

Şekil 2'de görüldüğü gibi kireç miktarının basınç mukavemetine etkisi önemlidir. Uçucu kül/kil oranının 4 olduğu seride kireç miktarı $\% 0$ değerinden $\% 15$ değerine kadar üstel olarak artırıldığında \%15 kireç miktarında 10,01 MPa basınç dayanımı elde edilmiştir. Daha yüksek kireç miktarlarında ise basınç dayanımı düşmektedir. Burada uçucu külün puzolanik etkisi ile beraber kirecin hidrolik bağlayıcılığı sebebiyle basınç dayanımını arttırdığı yorumlanabilir. Yapılan bir çalışmada ince boyutlu uçucu kül yüksek özgül yüzey alanı ile daha fazla kireç ile reaksiyona girme ve dolayısı ile yüksek puzolanik aktivite indeksinin elde edilmesini sağladığ 1 , $45 \mu \mathrm{m}$ 'dan ince taneli uçucu küllerin uzun dönemli kür süreleri sonunda dayanım değerlerinin yüksek olduğu, fakat erken dönemlerde düşük dayanımlar gösterdiği tespit edilmiştir [19].

Yüksek kireç miktarlarında ise kirecin zayıf dayanım özellikleri malzemenin özelliklerine yansımakta ve basınç dayanımlarını düşürdüğü değerlendirilmektedir. Bu deney setinde en çok dayanımı veren $\% 15^{\prime}$ lik kireç yüzdesi uygun değer olarak daha sonraki deney setinde sabit parametre olarak alınmıştır. Uçucu kül/kil oranının 2,33 olduğu seride kireç miktarı $\% 0$ değerinden $\% 15$ değerine kadar üstel olarak artırıldığında \%15 kireç miktarında 7,28 MPa en yüksek dayanım elde edilmiştir. Daha yüksek kireç miktarlarında basınç dayanımı düşmektedir. İki seri kıyaslandığında kireç oranı sabit uçucu kül ihtivası yüksek malzeme daha yüksek basınç dayanımına ulaşmış kireç miktarının artması ile basınç dayanımları bir düşüş göstermiştir. Elde edilen sonuç, uçucu kül ve dip kül kullanılarak yapılan araştırma ile de desteklenmekte olup söz konusu araştırmada da; uçucu kül ve çimento karışımlarının geleneksel kil tuğlalara kıyasla daha iyi performans gösterdiği ve basınç dayanımının 7,13 MPa ile 17,36 MPa arasında değiştiği, geleneksel tuğlalara alternatif olarak kullanılabileceği ve dolayısıyla sürdürülebilir kalkınmaya katkıda bulunabileceği sonucuna varılmıştır [20]. 


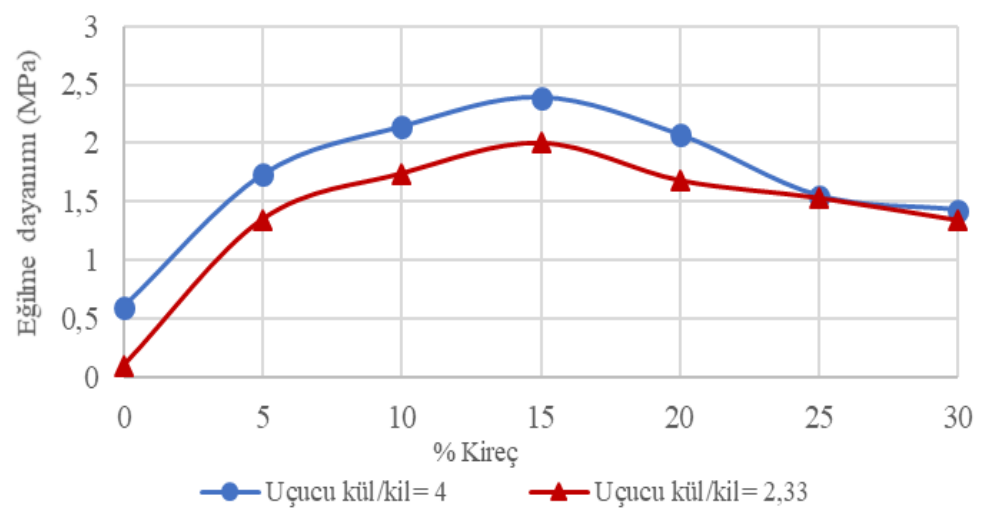

Şekil 3. Eğilme dayanımının kireç miktarına bağlı olarak değişimi (28 gün yaşta).

Şekil 3'de görüldüğü üzere uçucu kül/kil oranının 4 olduğu seride kireç miktarı $\% 0$ değerinden $\% 15$ değerine kadar üstel olarak artırıldığında \%15 kireç miktarında 2,39 MPa eğilme dayanımı elde edilmiş̧ir. Daha yüksek kireç miktarlarında ise eğilme dayanımı düşmüştür. Uçucu kül/kil oranının 2,33 olduğu seride ise kireç miktarı $\% 0$ değerinden $\% 15$ değerine kadar üstel olarak artırıldığında $\% 15$ kireç miktarında 2,0 MPa eğilme dayanımı elde edilmiş̧ir. Yüksek kireç miktarlarında kirecin zayıf dayanım özelliği malzemenin özelliklerine yansımış ve basınç dayanımlarında olduğu gibi eğilme dayanımlarında da düşüş gözlenmiştir. Yapılan benzer bir çalışmada uçucu kül (\%68), kireç (\%12) ve kum (\%20) karışımından elde edilen numunelerin basınç dayanımı incelenmiş, en yüksek basınç dayanımı 10,25 MPa olarak tespit edilmiştir [21].

\section{B. UÇUCU KÜL MİKTARININ YAPI MALZEMESININ DAYANIMINA ETKİİ}

Uçucu külün yapı malzemelerine etkisini incelemek üzere kireç/kil oranının 0,882 ve 0,588 değerleri bütün deneylerde sabit tutularak aynı kür şartlarında prizlendirilmiştir. Kür şartları ise doygun buhar ortamında $98^{\circ} \mathrm{C}$ sıcaklık, atmosferik basınçta 1 saat süre ve 28 günlük dayanımları olarak bu grup deneylerin tümünde sabit tutularak uçucu kül miktarı ilavesi değiştirilmiştir. Değişen uçucu kül miktarına bağlı olarak basınç dayanımının değişimi Şekil 4'de, eğilme dayanımının değişimi ise Şekil 5 'de verilmiştir.

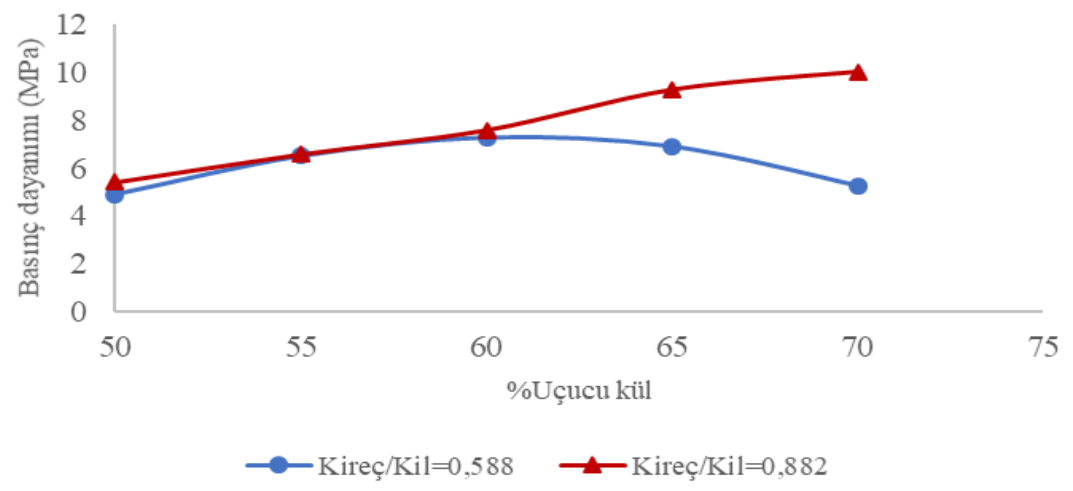

Şekil 4. Basınç dayanımının uçucu kül miktarına bağlı olarak değişimi(28 gün yaşta).

Şekil 4'de incelendiğinde kireç/kil oranının 0,882 olduğu seride basınç dayanımı uçucu kül miktarının $\% 50$ değerinden $\% 70$ değerine kadar üstel olarak artmış \%70 uçucu kül miktarında 10,03 $\mathrm{MPa}$ en yüksek basınç dayanımı elde edilmiştir. Bu deney setinde en çok dayanımı veren \%70'lik uçucu kül yüzdesi uygun değer olarak daha sonraki deney setinde sabit parametre olarak alınmıştır. Şekil 4'de kireç/kil oranının 0,588 olduğu seride ise basınç dayanımı uçucu kül miktarı $\% 50$ değerinden $\% 60$ değerine kadar üstel olarak artmış, \%60 uçucu kül miktarında 7,29 MPa en yüksek basınç dayanımı 
elde edilmiştir. Daha yüksek uçucu kül miktarlarında ise kirecin dolgu maddesinin miktarının artışından kaynaklanan numunede dağılma eğilimi göstermesinden \% 70 'den büyük deney sonuçları dikkate alınmamıştır. Burada sabit tutulan kireç/kil oranının bağlayıcılık açısından yetersiz kaldığı düşünülmektedir.

Betonda kum yerine uçucu kül kullanılan ve uçucu kül tane boyutunun kompozit malzemenin termal ve mekanik performansına etkisinin incelendiği çalışmada; uçucu külün ağırlık yüzdeleri $\% 10,30,50$, 70 ve 90 içeren çimento karışım numunelerinin test sonuçlarında kül katılma oranının arttıkça basınç dayanımı değerlerinin \%1,25-9,4 oranında arttı̆̆ı tespit edilmiştir [22]. Betonun basma dayanımı yükselirken çekme dayanımı azalmaktadır. Kireç/kil oranı yüksek olan numunelerde basınç dayanımının daha yüksek tespit edilmesi de çevre şartlarında oluşan dikalsiyum silikatın $\left(\mathrm{C}_{2} \mathrm{~S}\right)$ etkin rol oynamasından kaynaklanmaktadır. Betonda yüksek miktarda uçucu kül kullanımı ile yapılan çalışmada, ağırlıkça \%60'ın üzerinde bağlayıcı yerine geçen uçucu kül içeren ultra yüksek hacimli (UHVFA) betonda malzemeyi yapısal olmayan veya yarı yapısal uygulamalarla sinırlayan erken bir aşamada genellikle düşük basınç dayanımı sergilediği, 360 günlük yaşa kadar mekanik özelliklerin kaydedildiği ve betonun basınç mukavemetinin en yüksek $40 \mathrm{MPa}$ 'dan $60 \mathrm{MPa}$ 'ya çıkabildiği tespit edilmiştir [23].

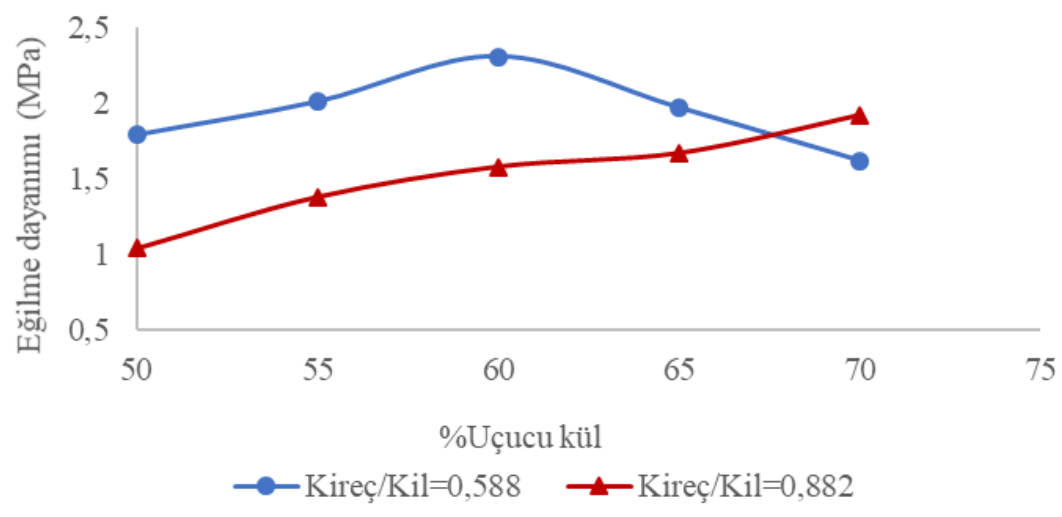

Şekil 5. Eğilme dayanımının uçucu kül miktarına bağlı olarak değişimi (28 gün yaşta).

Şekil 5 incelendiğinde kireç/kil oranının 0,588 olduğu seride uçucu kül miktarı \%50 değerinden \%60 değerine kadar üstel olarak artırıldığında \%60 uçucu kül miktarında 2,31 MPa eğilme dayanımı elde edildiği görülmektedir. Kireç/kil oranının 0,882 olduğu seride ise uçucu kül miktarı \%50 değerinden $\% 70$ değerine kadar üstel olarak artırıldığında \%70 uçucu kül miktarında 1,92 MPa eğilme dayanımı elde edilmiştir. Daha yüksek uçucu kül miktarlarında ise basınç dayanımı testlerinde olduğu gibi kirecin dolgu maddesinin miktarının artışından kaynaklanan numunede dağılma eğilimi göstermesinden \% 70'den büyük deney sonuçları dikkate alınmamıştır.

Yap1 malzemesinde kullanılan standart bağlayıcıların kullanım amacı hem yapı elemanını tek bir gövde gibi çalıştırmak hem de yapıda kullanılan yerlere göre basınç dayanımlarını karşılamaktır. $\mathrm{Bu}$ çalışmada, kullanılan uçucu külün bağlayıcı özelliği üzerine araştırmalar yapıldığı için yapı malzemesinin basınç dayanımları oldukça önem arz etmektedir. Alkali uçucu kül ile yapılan benzer bir çalışmada alkali kül malzemelerin altyapı sistemlerinde kullanımı, basınç dayanımı, çekme dayanımı ve mikro yapısı incelenmiş, basınç dayanımı düşük (0,075 MPa), eğilme dayanımı ise daha yüksek (8,2 MPa) tespit edilmiş, basınç dayanımlarının yapı malzemeleri için önemli bir özellik olduğu ortaya konulmuştur [24]. Yapılan başka bir uygulamada mermer tozu ve uçucu külün kullanılması ile üretilen polimer matriks kompozit malzemelerin eğilme deneyleri sonucunda en çok 3,2 $\mathrm{MPa}$ değere ulaşı1mıştır [25]. 


\section{BASINÇ VE EĞILME DAYANIMLARI ARASINDAKİ İLIŞKINIIN İNCELEMESİ}

Şekil 6'da görüldüğü üzere uçucu kül/kil oranı 2,33 (kireç/kil=0,588), $98^{\circ} \mathrm{C}, 1$ atm basınç ve 28 günlük kür şartlarında eğilme dayanımı en yüksek çıkan malzeme için denklem bulunmuş ve regresyon katsayısı hesaplanmıştır. Buna göre elde edilen doğrusal fonksiyonda bulunan regresyon katsayısı $\mathrm{R}^{2}=0,7569$ olup, bağıntının deneysel verileri oldukça iyi temsil ettiğini göstermiştir.

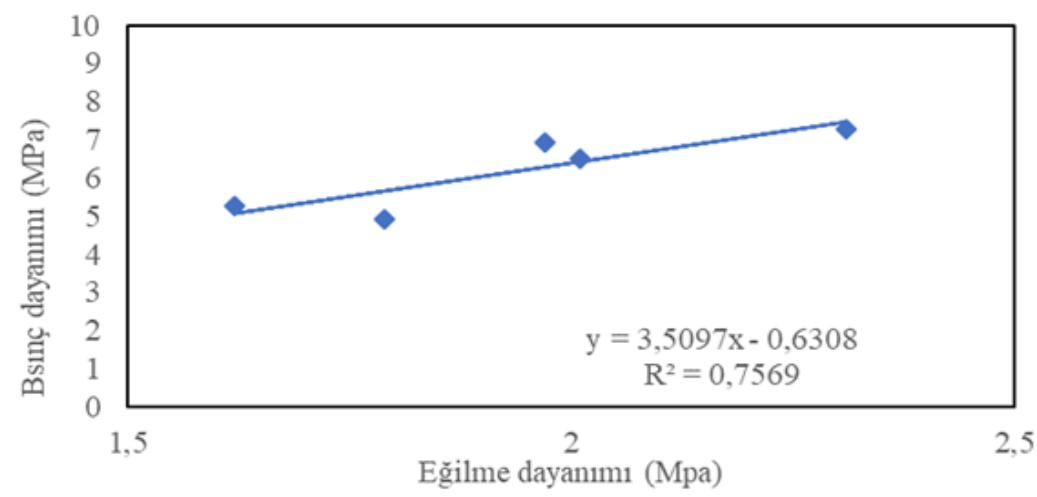

Şekil 6. Basınç dayanımının eğilme dayanımına göre değişimi, uçucu kül/kil:2,33 (28 gün yaşta).

Benzer şekilde, uçucu kül/kil oranı 4 (kireç/kil=0,882), $98^{\circ} \mathrm{C}, 1$ atm basınç ve 28 günlük kür şartlarında basınç dayanımı en yüksek çıkan malzeme için de denklem bulunmuş ve regresyon katsayısı hesaplanmıştır (Şekil 7). Buna göre elde edilen doğrusal fonksiyonda bulunan regresyon katsayıs1 $\mathrm{R}^{2}=0,9402$ olup, bağıntının deneysel verileri çok daha iyi temsil ettiğini göstermiştir.

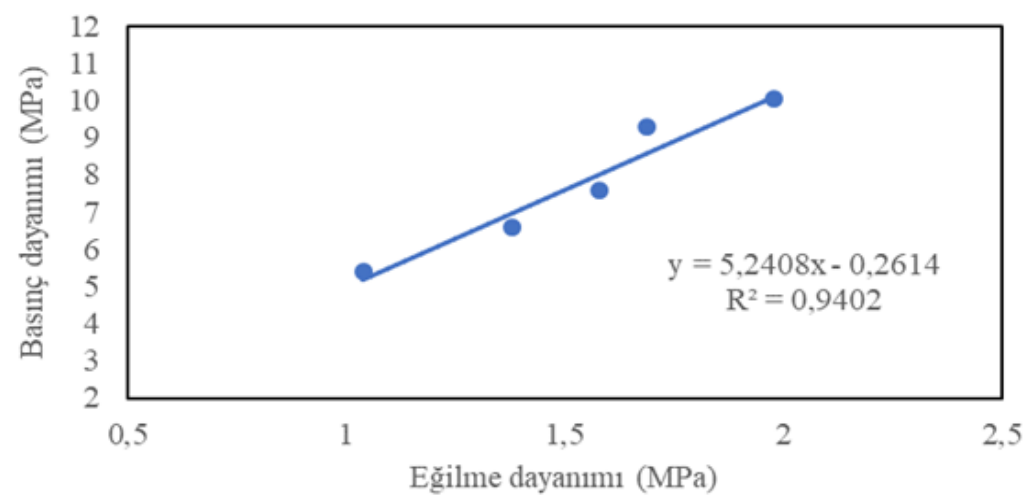

Şekil 7. Basınç dayanımının eğilme dayanımına göre değişimi; uçucu kül/kil:4 (28 gün yaşta).

\section{MIKROYAPI İNCELEMESI}

Üretilen numunelerin mikroyapı incelemeleri; Taramalı elektron mikroskobu (SEM) ve X ışınları kırılımı (XRD) cihazı ile yapılmıştır. Şekil 8'de basınç dayanımları ve eğilme dayanımları en yüksek sonuçları veren numunelerin taramalı elektron mikroskobu ile çekilmiş görüntüleri ve Şekil 9 ve 10'da basınç dayanımları ve eğilme dayanımları en yüksek sonuçları veren numunelerin X-1şınları kırılımı (XRD) difraktogramları verilmiştir. 


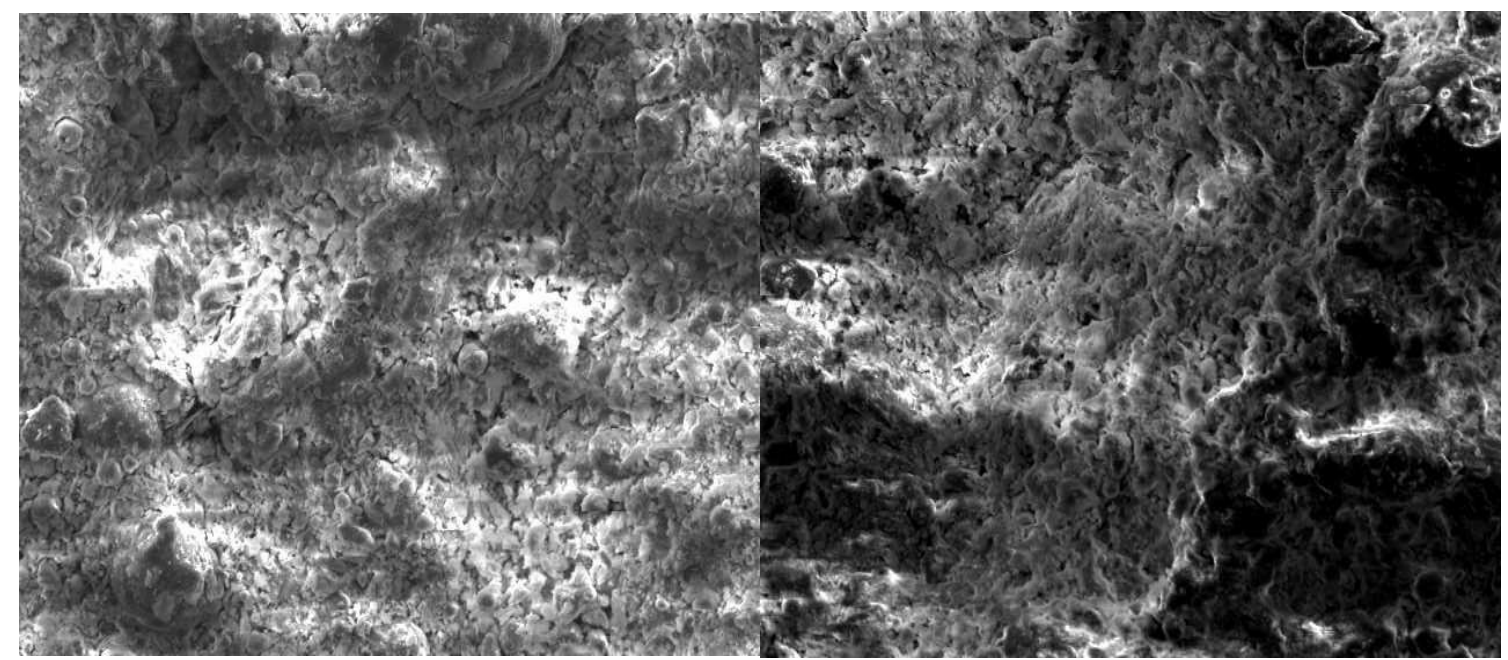

(a)

(b)

uçucu kül/kil: 2,33

uçucu kül/kil: 4

Şekil 8. Numunenin taramalı elektron mikroskobunda 500 kez büyütülmüş görüntüsü (28 gün yaşta).

Şekil 8 (a)'da görülen taramalı elektron mikroskobu görüntüsü eğilme dayanımında en çok değeri veren numuneye aittir. Detaylı incelendiğinde uçucu kül taneciklerinin kil tanecikleri arasına homojen dağıldığ1 ve aderansı sağladığı görülmektedir. Puzolan özellikteki uçucu külün silikat ve alüminat esaslı olması ve dikalsiyum silikat oluşumuna sebebiyet vermesi daha kuvvetli yapı oluşturmaktadır. Yine yüzeyde porozitenin (b)'de ki kadar yoğun olmadığı da görülebilmektedir. Sadece uçucu külün bağlayıcı özelliği değil kirecin de en çok eğilme dayanımı vermesinde katkısı oldukça fazladır. Bağlayıcı özellik gösteren uçucu külün ve kirecin malzeme üretim aşamasında homojen olarak karıştırılması ve oranları elde edilen dayanımdaki etkin rollerden birisidir. Yüksek plastisiteli killi zeminlerin termik santral atığı uçucu küller ile karıştııılıp, sıkıştırılarak mekanik özelliklerinin iyileştirilmesine yönelik yapılan çalışmada, killi zeminlere ağırlıkça \%5 ila \%20 arasında değişik oranlarda uçucu kül katılarak elde edilen karışımların mukavemet değerlerinde önemli oranda artışlar gözlendiği, numunelerin SEM sonuçları incelendiğinde ise kil ve kül mineralleri arasında meydana gelen bağların silikat ve alüminatlarca oluşturulan jeller tarafından sağlandığı ve oluşturulan zemin karışımlarında bileşenlerin dane çapında artışa, çimentolaşmaya, artan kür süresiyle birlikte numunelerin gevrek bir yapıya bürünmelerine sebep olduğu raporlanmıştır [26].

Şekil 8 (b)'de görülen taramalı elektron mikroskobu görüntüsü basınç dayanımını en çok veren numuneye aittir. Uçucu kül oranının yüksek oluşu ve görüntüdeki yüzeyde olduğu gibi yapıda yayılmış uçucu kül tanecikleri yapıya ve dayanıma ne denli olumlu etkilerde bulunduğunu açıklamaktadır. Porozite oranının da yüzeyde gözlendiği ve bu etkenin eğilme ve basınç dayanımlarını olumsuz yönde etkilediği de görülebilir. SEM fotoğraflarından, taneler arasındaki boşluklar ve heterojenlikten dolayı bağlayıcı malzeme oranının malzeme içerisindeki dağılımı etkilediği, buna bağlı olarak eğilme ve basınçta değişmeler oluşturduğu anlaşılmaktadır. Nitekim, uçucu külden kompozit malzeme üretmek amaçlı yapılan çalışmada, $\% 5$ uçucu kül $\% 95$ polipropilen içeren nanokompozitin farklı bölgelerinden SEM görüntüleri alınmış ve yapılan değerlendirmeler neticesinde nanopartiküllerin polipropilen matrisin içerisinde homojen bir şekilde dağıldığı gözlenmiştir [27].

Şekil 9'da eğilme dayanımı en yüksek olan numunenin X-1şınları difraktogramı görülmektedir. En yüksek pik noktası olarak tespit edilen quartz miktarının çokluğu bize uçucu kül miktarının numune içerisinde ne derece önemli rol oynadığını göstermektedir. Quartz'ın yanı sıra malzemede başlıca kristal fazlar olarak hematit, anortit, serbest kireç ve kilden ileri gelen illit-montmorillinite de rastlanılmıştır. Camsı fazın $27^{\circ} 2 \theta$ değerinde en yüksek değerde olması ve $30^{\circ} 2 \theta$ değerini de alacak şekilde yayılması fazın silissi ve kireçsi bir yapıda olmasından kaynaklanmaktadır. 


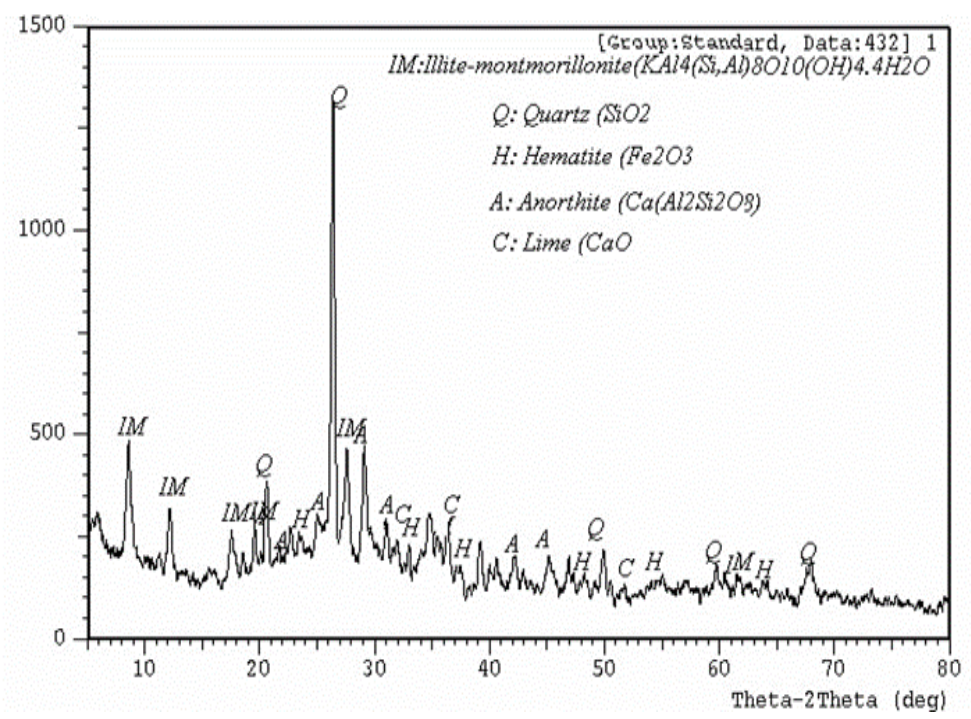

Şekil 9. Numunenin X-ışınları difraktogramı, kireç/kil: 0,588 (28 gün yaşta).

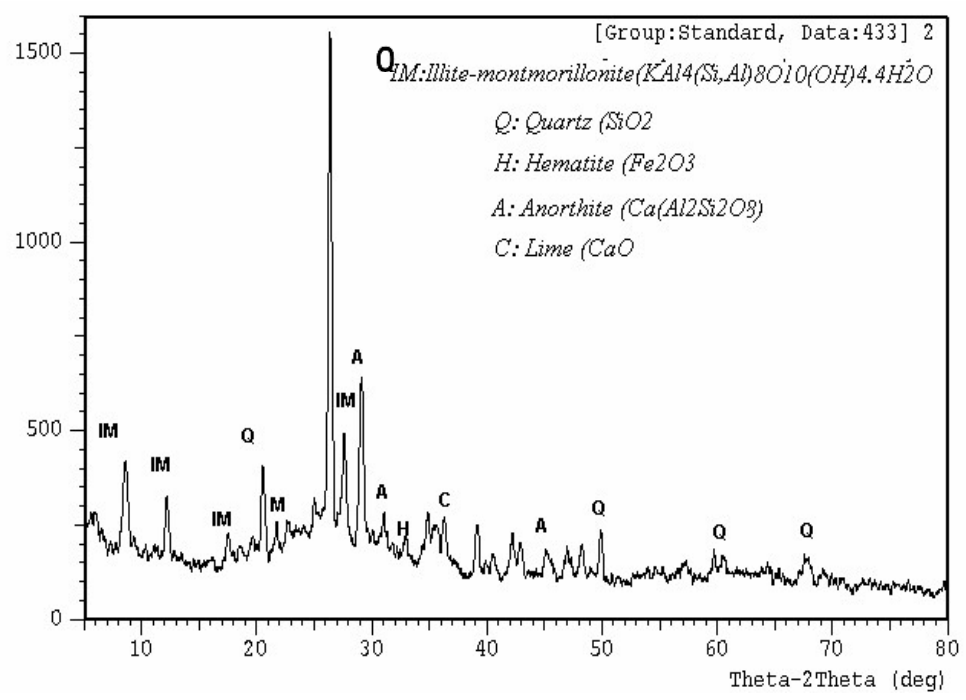

Şekil 10. Numunenin X-lşınları difraktogramı, kireç/kil: 0,882 (28 gün yaşta).

Şekil 10'da basınç dayanımı en yüksek bulunan numunenin X-ışınları difraktogramı görülmektedir. Üretilen malzemede başlıca kristal fazlar olarak quartz, hematit, anortit, serbest kireç ve kilden ileri gelen illit-montmorillinite rastlanılmıştır. En yüksek pik noktası olarak tespit edilen quartz miktarının çokluğu uçucu kül miktarının numune içerisinde miktarca çokluğunu ve malzeme içerisinde dağılımını göstermektedir. Mukavemet artışının reaksiyon sonucu oluşan anortit fazından kaynaklandığı düşünülmektedir.

\section{IV.SONUC}

Türkiye'nin en büyük sektörlerinin başında bulunan çimento sektörünün çevreye olan etkileri tartışılamayacak kadar önemlidir. Çimentonun su ile hidratasyonu sonucunda doğaya verdiği $\mathrm{CO}_{2} \mathrm{ve}$ sera gazları çevresel sorun teşkil etmektedir. Bu araştırmada, puzolanik uçucu külün bağlayıcı olarak kullanılabilirliği üzerine çalışılmış, atık malzeme ve çevre kirletici bir rol oynayan uçucu külün yapı malzemelerinde kullanılabileceği ve 28 günlük dayanımları arttığı görülmüştür. Kil oranları yüksek ve uçucu kül oranları düşük olan numunelerin düşük dayanımlarından dolayı kireç oranları sabit kalmak 
şartı ile uçucu kül oranları arttırılıp kil oranları düşürülmüştür. Bu durum uçucu kül miktarının ve kireç oranının artması ile mekanik dayanımda artışa sebebiyet vermiştir.

Basınç dayanımında en yüksek sonuç 10,03 MPa, eğilme dayanımında en yüksek sonuç 2,39 MPa elde edilmiştir. Yoğurma suyu miktarı, kil oranı yüksek numunelerde daha fazla olduğundan, kilin su emme özelliğine bağlı olarak şişmesi ve yoğrulma esnasında kapilerite ile gözeneklere aldığı su miktarının doğal kurutma işlemi esnasında uçması sonucu bünyesinde boşluklar oluşturması mekanik dayanımlarda düşüş̧e neden olmuştur. Üretilen malzemenin ortalama yoğunluğu $3,167 \mathrm{~g} / \mathrm{cm}^{3}$ bulunmuş, beton yoğunluğuna yakın bir değer elde edilmiştir. XRD difraktogramında görülen fazlar içerisinde çok güçlü bir seramik olan anortitin oluşması mukavemet artışına neden olmuştur. $\mathrm{Bu}$ yapının yanı sıra uçucu külden gelen quartz, hematit, serbest kireç ve illit-montmorrolinit fazlarına da rastlanmıştır.

Sonuç olarak uçucu kül katkılı hidrolik bağlayıcı malzemelerin yüksek basınç dayanımı nedeniyle, yapının basınç kuvveti yüksek olan noktalarında, tuğla duvar yerlerinde, kaset, nervürlü döşemelerde kullanımı düşünülmelidir. Eğilme dayanımlarının basınç dayanımlarına oranla düşük olması, taşıyıcı sistemlerde betona göre dayanım gösteremeyeceğinin ifadesidir.

TEȘEKKÜR: Bu çalışma, 2001K120590 kod'lu DPT Projesi kapsamında yürütülmüş olup DPT yöneticilerine teşekkürlerimi sunarım.

\section{KAYNAKLAR}

[1] H. Y. Aruntaş, "Uçucu küllerin inşaat sektöründe kullanım potansiyeli," Gazi Üniversitesi Mühendislik Mimarlık Fakiltesi Dergisi, c. 21, s. 1, ss. 193-203, 2006.

[2] T. Çiçek and Y. Çinçin, "Use of fly ash in production of light-weight building bricks," Construction and Building Materials, vol. 94, pp. 521-527, 2015.

[3] E. Şadoğlu ve Ü. Çalık, "Kireç ve perlitle stabilize edilen yüksek plastisiteli kil zeminin geçirimliliği," Gazi Üniversitesi Mühendislik Mimarlık Fakiltesi Dergisi, c. 35, s. 2, ss. 551-561, 2020.

[4] P. Ö. Erdoğan ve H. M. Başar, "Deniz dibi tarama malzemesi, kömür uçucu külü ve atık döküm kumunun hafif agrega olarak geri kazanımı," Gazi Üniversitesi Mühendislik Mimarlık Fakiltesi Dergisi, c. 34, s. 3, ss. 1377-1394, 2019.

[5] Y. Yılmaz, "Beton üretiminde uçucu kül ve yüksek fırın cürufu kullanılmasının etkileri ve maliyet analizi," Yüksek lisans tezi, Biyosistem Mühendisliği, Fen Bilimleri Enstitüsü, Namık Kemal Üniversitesi, Tekirdağ, Türkiye, 2014.

[6] N. Nordin, M. M. A. B. Abdullah, M. F. M. Tahir, A. V. Sandu and H. Kamarudin, "Utilization of fly ash waste as construction material," International Journal of Conservation Science, vol. 7, pp. 161-166, 2016.

[7] M. Çavuş, M. Dayı, H. Ulusu ve H. Y. Aruntaş, "Sürdürülebilir Bir Yapı Malzemesi Olarak Kerpiç,” 2. Uluslararası Sürdürülebilir Yapı Sempozyumu, Ankara, Türkiye, 2015, ss. 184-192.

[8] S. Abbas, M. A. Saleem, and M. J. Munir, "Production of sustainable clay bricks using waste fly ash: Mechanical and durability properties," Journal of Building Engineering, vol. 14, pp. 7-14, 2017.

[9] Çimento-Bölüm 1: Genel çimentolar-Bileşim, Özellikler ve Uygunluk Kriterleri, Türk Standartları Enstitüsü TS EN 197-1, 2012. 
[10] Standard Specification for Coal Fly Ash and Rawor Calcined Natural Pozzolan for Use in Concrete, American Society for Testing and Materials ASTM C 618-19, 2019.

[11] Uçucu Kül-Betonda Kullanılan-Bölüm 1: Tarif, Özellikler ve Uygunluk Kriterleri, Türk Standartları Enstitüsü TS EN 450-1, 2012.

[12] P. Türker, B. Erdoğan, F. Katnaş ve A. Yeğinobalı, "Kimyasal, mineralojik ve morfolojik analiz sonuçları, Türkiye'deki uçucu küllerin sınıflandırılması ve özellikleri”, Ankara, Türkiye, Türkiye Çimento Müstahsilleri Birliği ArGe Enstitüsü, Fersa Matbaacılık, 2009, ss. 19-89.

[13] Çimento Deney Yöntemleri-Bölüm 3: Priz Süreleri ve Genleşme Tayini, Türk Standartları Enstitüsü TS EN 196-3, 2017.

[14] Sular-İnsanî Tüketim Amaçlı Sular, Türk Standartları Enstitüsü TSE 266, 2010.

[15] Beton-Sertleşmiş Beton Deneyleri-Bölüm 2:Dayanım Deneylerinde Kullanılacak Deney Numunelerinin Hazırlanması ve Küre Tabi Tutulması, Türk Standartları Enstitüsü TS EN 12390-2, 2019.

[16] Beton-Sertleşmiş Beton Deneyleri-Bölüm 5: Deney Numunelerinin Eğilme Dayanımının Tayini, Türk Standartları Enstitüsü TSEN 12390-5, 2019.

[17] O. Şimşek, Beton Bileşenleri ve Beton Deneyleri, Ankara, Türkiye, Seçkin Yayınc1lık, 2011.

[18] Beton-Sertleşmiş Beton Deneyleri-Bölüm 4: Basınç Dayanımı-Deney Makinelerinin Özellikleri, Türk Standartları Enstitüsü TS EN 12390-4, 2019.

[19] B. Akkaya ve İ. Toroğlu, "Uçucu külün boyutu ile puzolanik aktivitesi arasındaki ilişkinin incelenmesi," Karaelmas Fen ve Mühendislik Dergisi, c. 7, s. 2, ss. 412-418, 2017.

[20] S. Naganathan, A. Y. O. Mohamed, S. Jamaliand K. N. Mustapha, "Performance of bricks made using fly ash and bottom ash," Construction and Building Materials, vol. 96, pp. 576-580, 2015.

[21] T. Çiçek and T. Tanrıverdi, "Lime based steam auto claved fly ash bricks," Construction and Building Materials, vol. 21, no. 6, pp. 1295-1300, 2007.

[22] A. Biçer, "Effect of fly ash particle size on thermal and mechanical properties of flyashcement composites," Thermal Science and Engineering Progress, vol. 8, pp. 78-82, 2018.

[23] J. Yu, C. Lu, C. K. Y. Leung, G. Li, "Mechanical properties of gren structural concrete with ultrahigh-volume fly ash," Construction and Building Materials, vol. 147, pp. 510-518, 2017.

[24] S. Jahanian and H. Rostami, "Alkali ash material, a novel material for infrastructure enhancement," Engineering Strucures, vol. 23, no. 6, pp. 736-742, 2001.

[25] M. Gürü, S. Tekeli and E. Akın, "Manufacturing of polymer matrix composite material using marbledust and fly ash," Key Engineering Materials, vol. 336-338, pp. 1353-1356, 2007.

[26] F. Acar, "Kutlubey-Yazıcılar bölgesi killerinin fiziksel ve mekanik özelliklerinin Çatalağzı uçucu külü ile stabilizasyon," Yüksek lisans tezi, İnşaat Mühendisliği, Fen Bilimleri Enstitüsü, Bartın Üniversitesi, Bartın, Türkiye, 2019. 
[27] K. Bitirim,“Termal santrallerden elde edilen uçucu kül tabanlı nanopartiküllerin türlerinin belirlenmesi, yapisal karakterizasyonu ve termoplastik nanokompozit dolgu malzemesi olarak kullanım potansiyellerinin araştırılması," Yüksek lisans tezi, Mikro ve Nanoteknoloji, Fen Bilimleri Enstitüsü, TOBB Ekonomi ve Teknoloji Üniversitesi, Ankara, Türkiye, 2019. 